ACTA UNIVERSITATIS LODZIENSIS

FOLIA LITTERARIA POLONICA 8(38) 2016

http://dx.doi.org/10.18778/1505-9057.38.04

Arkadiusz Morawiec*

\title{
Shoah in Marian Pankowski's Literary Art
}

The place of Marian Pankowski's literary art in Polish concentration camp literature (Lager literature) is unique, supposedly close to Tadeusz Borowski's short stories and his "non-Manicheistic" and non-martyrological vision of camp reality, however distant from that of the This Way for the Gas, Ladies and Gentlemen (Prosze państwa do gazu) author by the sheer literary dimension co-created by a (not rare) ostentatious creativity. Moreover, we find a rich variety of formal searches in Pankowski's art - a range of specific forms and style - as well as venturing into areas unexplored or haunted by this type of writing (for instance sexuality in the camp) ${ }^{1}$. The author himself derived the uniqueness of his writing from the independence of his writing as an emigrant, situated beyond connections and the censorship pressure of both national (institutional and social) and emigration (because this one also existed) ${ }^{2}$ and, what is perhaps most important of them all, from liberating himself from the concentration camp syndrome (KZ-syndrome) $)^{3}$.

* Dr hab. prof. UŁ, University of Łódź, Faculty of Philology, Department of Polish Literature of the $20^{\text {th }}$ and $21^{\text {st }}$ Century; e-mail: arkadiuszmorawiec@poczta.fm.

${ }^{1}$ For further information about camp plot in Pankowski's writing see A. Morawiec, Zmagania z tematem lagrowym w twórczości Mariana Pankowskiego, in: idem, Literatura w lagrze, lager w literaturze. Fakt - temat-metafora, Wydawnictwo WSHE w Łodzi, Łódź 2009.

${ }^{2}$ Considering the whole thing from a psychological point of view one should also take internal censorship into account - in case of Pankowski, compared with other authors, hardly restrictive. In his novel Matuga is coming, containing a concentration camp plot, the title narrator-hero, performing in many places as author's porte-parole, speculates: "To preserve it all. Oh, they will not believe nevertheless. [...] I will tell them [...] - you know, as I was standing, as I am standing now - and will stand by the door - and these columns by columns are returning to the camp. First foursome, stout and strapping (upper beds! upper beds!), but I won't tell them that)" (M. Pankowski, Matuga idzie. Przygody, nakładem autora, Bruxelles 1959, p. 64). "Upper beds", narrator has informed us about (the reader, and not future listeners of narrator-hero, knows about that), mean high-ranking prisoners, using services, sexual among other things (exposed in the novel!) of prisoners being on the lower level of the camp ladder (ibidem, pp. 63-64).

${ }^{3}$ See Polak w dwuznacznych sytuacjach. Z Marianem Pankowskim rozmawia Krystyna Ruta-Rutkowska, IBL Wydawnictwo, Warsaw 2000, pp. 36-37. 
Pankowski's wrestling with camp subject matter as much as with own experience were marked in turn by: a poem entitled Auschwitz from 1946, a novel entitled Matuga is coming, a drama entitled Theatring over holy borsch, a short story entitled My SS Rottenführer Johanna, crowned by a work - published in 1998 - From Auschwitz to Belsen ${ }^{4}$. In connection with this text the author mentioned the "Auschwitz Thing, lived, realized after years and thought jealously, as a unique work, far from post-Auschwitz manicheistic books"5.

And when it seemed that the writer ultimately - in this documentary-creative work bearing the subtitle Adventures - voiced his lager topic, the Shoah or the extermination of Jews, inevitably connected with camp matters, became very clearly prominent in his literary production. A special expression of this was Travel of my wife's parents to Treblinka from $2003^{6}$. This drama, I pay more attention to in the further part of this sketch, was not the only text by the writer about the extermination of Jews. Neither was it the only one in which the extermination took place within the lager.

In the "fragment of a poem" entitled Auschwitz that was published shortly after the end of WWII" a "whole-human" perspective or tendency (which is expressed with the words "people", "humankind") dominates, a lyrical subject saying - a Polish poet - notices Jews clearly: "Tu - wróg wytępia narodowe Gniezno, / Tu - Izraela z sił wycieńcza gorąc" (Here - the enemy eradicates national Gniezno, / Here - the heat emaciates Israel of its strength"). The highlighting of Jews amongst tormented people was dictated in part by an Old Testament stylization of the poem (visible for instance in the poet's call addressed to Yahweh: "Save your people!"), nonetheless limited to it only. Being in Auschwitz, Pankowski realized very well the uniqueness of the fate of Jews. A compelling expression of this, addressed by the lyrical subject of Auschwitz poem to a recalled Psalmist, was warranted:

Opisz komorę grobową i płaską,

gdzie tysiącami padają Żydowie!

${ }^{4}$ M. Pankowski, Auschwitz. Fragment poematu, in: idem, Pieśni pompejańskie, R.-J. Stenuit, Bruxelles 1946 (original: "Wiadomości" 1946, no 29); idem, Matuga idzie...; idem, Teatrowanie nad świętym barszczem, Oficyna Poetów i Malarzy, London 1968 (original: "Oficyna Poetów" 1968, issue 2); idem, Moja SS Rottenführer Johanna, in: idem, Złoto żałobne, Millennium, Koszalin 2002 (original: "Fraza" 1997, issue 4); Z Auszwicu do Belsen. Przygody, Czytelnik, Warsaw 2000. (original: "Twórczość" 1998, issue 5). One can add to this list a novel entitled Rudolf (London 1980), but not without reservation. The narrator-hero of this work, stylized to be an author, has a camp past but it does not constitute a leading thread: camp experience in Rudolf is one of "the arguments" in dispute over values, followed by the narrator with a title homosexual-German, an adherent of an extremely hedonistic attitude.

${ }^{5}$ Idem, a letter to A. Morawiec from 25 January 2002 (in the possession of the addressee).

${ }^{6}$ Idem, Podróż rodziców mej żony do Treblinki, "Dialog” 2003, issue 12.

${ }^{7}$ Idem, Auschwitz..., pp. 6-12. 
I czeluść opisz z okropnego głazu,

gdzie giną truci gazem - jak zarazą!... ${ }^{8}$

[Describe the death chamber and a plain one, where Jews fall in thousands!

And describe the abyss from a terrible stone

where they die poisoned by gas - like the disease!...]

Obviously, concentration camps and, especially, camps of (immediate) extermination were not the only areas of Shoah, so the theme of Jewish extermination recurring in Pankowski's works appeared not only in the context of lager. One of the literary testimonies of murdered millions in his output was a poem entitled Homer from 1947. It is worth recalling this little known text in full because it is where the way to words spoken by the writer in 2007 leads: "in Polish literature I am a Jew" ${ }^{9}$ :

Kołem nieporuszonym

stali nade mną Żydzi.

- Bracia, rzekłem.

Pochylili głowy

i popiół wysypał się z orbit.

Biłem się w piersi. A z drugiej strony ciszy

zaśpiewał w rytm epopei

Homer

siedmiomilionowy. ${ }^{10}$

${ }^{8}$ See also this recollection of the writer: "When we were going to work, tidily dressed, singing, I saw more than a hundred of Jews behind the fence - women, children with suitcases - who at our sight slightly smiled. They imagined that their stay in the camp would be like this. In the evening, when I returned to the camp, there were only suitcases left lying. After eating soup I came out of the barrack to meet my friends and saw red tongues of fire over crematory. And then I thought: Jews smiling as they did in the morning are now going to God and He is not there" (W literaturze jestem Żydem, [an interview with M. Pankowski] interviewed by K. Janowska, "Gazeta na Święta" [added to "Gazeta Wyborcza" 2007, issue 300], p. 20).

${ }^{9}$ Ibidem, p. 21. See remarks to literary and emphatic commenting by Pankowski in the name of annihilated Jews: P. Krupiński, "Prawując się z milczacym Bogiem". Mariana Pankowskiego rozrachunki auszwickie, in: Ślady obecności, S. Buryła, A. Molisak (eds.), Universitas, Cracow 2010, pp. 155-156.

${ }^{10}$ M. Pankowski, Homer, in: idem, Sto mil przed brzegiem, PIW, Warsaw 1958, p. 51. Incidentally, beating one's breasts, feeling guilty because of emptiness left after Jewish brothers, can be also found in Pankowski's poem: Sanok Jews / Żydzi sanoccy (vol. Podplomyki from 1951): "I feel 
[A wheel unmoved

Jews were standing over me.

- Brothers, I said.

They lowered their heads

and ash sprinkled from their orbits.

And I beat my breasts.

And on the other side of silence

Homer

sang to the rhythm of the epic

seven million.]

The first work, better known than the poems in Pankowski's output, was a work where Shoah played an important role was the drama entitled Cockchafers (Chrabaszcze), published in $1970^{11}$. Its action took place in a contemporary Parisian apartment of a respected stage designer Róża Karp, a Polish Jew, who as a young girl escaped from a transport going to a death camp. She managed to survive thanks to a Polish family that hid her beneath the pigsty. A fundamental part of the drama is a dialogue between Madame Karp and Stanisław Szeleściński, a journalist from Poland. We find here plots known from a lager drama written a short time earlier: Theatring over holy borsch, containing anti-veteran and antimartyrological features. This "theatring" made broader and broader circles in Pankowski's creative output. It embraced, a characteristic thread of Pankowski's (post)Holocaust writing, present day issues, among them Polish - official, institutionalized sometimes ideologically falsified and simultaneously characteristically necrophilic, politically paid and literally mercantilized - memory of Jews.

The journalist informed Róża Karp that she is the only living Jewish survivor from an unnamed town, situated somewhere in Lesser Poland. The visitor from Poland cared, as he stated, about "moral help" on behalf of the survivor. He said:

[...] we desire so that you know that your hometown remembers that it preserves the memory of those... who had left... and had been... brothers to us. Our peo-

guilty being able to ask our land about your ashes" (as cited in: "Bez tytułu", nr 14 [Sanok 2012], p. 11). We will meet Jews from Sanok, going to death camp, after half-century in a moving scene from a drama: Travel of my wife's parents to Treblinka.

${ }^{11}$ Idem, Chrabaszcze (Widowisko narodowe choć wyssane z palca), Oficyna Poetów i Malarzy, London 1970. I locate quotations from a reprint enclosed in a volume Polski dramat emigracyjny 1939-1969. Antologia, D. Ratajczakowa (ed.), Lektor, Poznań 1993; I precede page number with letter C. Cockchafers was staged by Wroclaw theatre "Kalambur" in 1990. 
ple care for this memory... In every district of our town there are created... out of themselves! Local committees for building a monument for victims of the ghetto. (satisfied) A monument by a monument! And then all these conventions, these annual pilgrimages... (C 865).

Madame Karp replies ironically:

Mister... it's cemetery tourism. You pay the amount of dollars and can standing there on the crematory fields put your hand into decayed ashes. And if you are lucky - you'll find a blackened jaw in this mustiness... with all its golden teeth pulled out. You want... me to smile with this jaw... inaugurate... (C 866).

Finally, the journalist achieved his intended aim by means of moral blackmail:

[...] so, I can see that one of the martyrological pages of Jewish nation will remain blank. [...] Or maybe these people, these simple people, where you, professor, were during the occupation, still stink for you... (C 867).

A motif of a farcically treated and institutionalized historical memory ${ }^{12}$ did not exhaust the issues of Cockchafers. Apart from a dialogue of two characters and actually weaving throughout, in the Parisian apartment (or on the stage) according to the words of the journalist "irrational Nativity play takes place" (C 877) - scenes invoked by WWII and post-WWII recollections of Róża. This staging ("theatring") of the traumatized memory of the hero enriches the drama by the still touchy questions of Polish Jewish contacts, left unsettled unambiguously and rather exasperatedly by Pankowski (still, that is at the moment the drama was written, just after March of 1968, defined by pronouns "ours" versus "yours"), which comprised of: Polish anti-Semitism, enrichment of Polish on Jewish tragedy, but also hiding Jews by Polish people risking their lives during war, pro-Soviet sympathies of Jews (and a stereotype of Judeo-Communism) and their haughty attitude towards Polish people.

Pankowski returned to some of these above-mentioned questions years later in one of his last books, in a short story entitled There used to be a Jewish woman, and there is no more Jewish woman now (Była Żydówka, nie ma Żydówki) ${ }^{13}$. This

${ }^{12}$ It should also be mentioned that the first monuments in the area of former death camps in Bełżec, Chełmno, Sobibór and Treblinka were erected (as late as!) in the 1960s. They usually were silent about the fact that mainly Jews died in these places: the propaganda of Polish People's Republic preferred to mention of "victims of many nationalities".

${ }^{13}$ Idem, Była Żydówka, nie ma Żydówki, Wydawnictwo Krytyki Politycznej, Warsaw 2008 (the original entitled Nie ma Żydówki: "Twórczość" 2007, issue 8). I localize further quotations according to book edtion, preceding page number with a letter B. 
work, dedicated to his deceased (1972) wife Regina of Ferns Pankowska, was connected with the drama Cockchafers by a motif of a Jewish "saved one". Digressing over the choice of the name for his character, the narrator, standing in for the author, stated:

When I repeat "Fajga", as if I was welcoming my wife returning from beyond the seven waves of Charon's river. This name will be given in the novel to a young Jewish woman, the only one saved from a May transport to gas chambers (B 10).

Although the fate of Regina Fern and the protagonist of the work, Fajga Oberlender, were partly similar - both eluded Shoah - it is impossible to see the prototype of the protagonist in Marian Pankowski's wife. It can, however, be assumed that the war fate of Regina Fern was an inspiration to pick up the touchy and not easy to get on with question of the Polish Jewish relations. But also - I will add - the touching matters of a more general nature, among them theodicy in the presence of Auschwitz and the attitude of the Vatican, strictly speaking Pope Pius XII, to the Holocaust. The narrator, whose voice could be regarded as contradictory to Pankowski's opinion not getting himself embroiled into complicated elucidations, and rather not encouraging discussion, states trenchantly: "Only I know that in those imprisoned years The Creator was on holidays in a country wo die Zitronen blühen and played patience in Castel Gandolfo" (B 8).

A short story entitled There used to be a Jewish woman, and there is no more Jewish woman now, in spite of digressions scattered in it, is not a discursive elucidation, an elucidation of undiscursive reasons; it is a story to which questions connected with Shoah, that are vividly discussed not only in Poland at the turn of the $21^{\text {st }}$ century, are coupled. Anti-Semitism should be distinguished among them and put as a quasi-treatise, analysis of the ideological mechanisms that functioned for centuries, whose purpose was the dehumanization of the image of the Jew, leading to exclusion and, as a consequence, what took place in the $20^{\text {th }}$ century, planned extermination. Remembering her situation during the occupation, the heroine states: "I ceased being regarded as a human being" (B 41). This assertion, what is important, is an expression (and accusation) not only aimed at the German attitude to Jews, but also the Polish attitude to Jews. It can seem surprising as Fajga Oberlender owes her rescue to Polish people who were risking their lives hiding her; moreover, she regards Poland as her fatherland (B 37). On the other hand, we find in this text suggestions that both the heroine, relating her occupation life to American Jews and the narrator left some things regarding the ways of rescuing and its cost unsaid. The author is not silent about the material benefits Polish people gained in connection with the disappearance of their neighbours and the Polish dislike of saved Jews coming back to houses that were (no longer) theirs previously detailed in Cockchafers. Answering the question why she had 
not come back to her home Fajga answers: "Other people are living there... They would say 'You want to take our home?! Isn't it enough that you are alive!'” (B 66) Fajga, a Polish Jew, is a stranger anyway, everywhere and for everyone. Germans wanted to annihilate her; for American Jews, who receive her in 1950, her fate is incomprehensible, thus, for them she is not entirely theirs - these "relatives-norelatives" are hers for her in inverted commas only (B 13). Pankowski exposed in his work a radical distinctiveness between the fates and worlds of Eastern European Jews and overseas Jews.

This Polish writer, a husband of a Jewish woman, was occupied in the first stance by the Polish-Jewish relations - unhesitatingly non-harmonious. Exposed in a short story as a source of mutual strangeness, incomprehension that shape mentality of both nations is a messianic idea. Jews, maintaining their distinctiveness and "proud of their jealous strangeness" (B 5), diligently guard their chosen nation status but the Polish (Christians) are hard pressed to drop their conviction of the unique role they play in history.

We, the inhabitants of European Nowhere Lands [i.e.: Poland - A.M.] are jealous of Your priority in history of suffering of the nations, therefore we cannot comprehend the enormity of the Jewish wrong (B 66).

In an earlier fragment of the text the narrator states:

Nobody will deny that even though time of common, religious or Nazi oppression of European Jews had gone by and Treblinka and Auschwitz are museums now where grandsons of victims take photos, standing on family ashes, Jews still remain strangers to us. [...] To us Christians [...] Jews are definitely alone (B 29-30).

A short story entitled There used to be a Jewish woman, and there is no more Jewish woman now is, despite all this, quite distant from (numerous) provocative accomplishments of Pankowski. The elementarily nostalgic, sentimental tone of this work could be influenced by the memory of the woman of the dedication - the "saved" wife of the writer who owed her survival to Polish people. Pankowski would not have been himself if he had not dwelled - always multidimensional and simultaneously frequently unpleasant - upon truth, if he had not questioned stereotypes and notices and if he had not at least in the end of the short story, in the Epilogue written in rhyme, presented himself in the attire of an embittered jester ${ }^{14}$. And, as usual, perversely:

\footnotetext{
${ }^{14}$ Incidentally, the narrator, mentioning ash coming from burnt Jews hovering over Auschwitz crematorium calls himself "alive clown in navy blue stripes with a number in the place of the star" (B 6).
} 
Żegnajcie... nie, witajcie!

uszminkowani popiołem aktorzy,

predestynowani

do odgrywania kapitalnej jednoaktówki

pod tytułem Znowu getto w ptomieniach!.

To perła naszego repertuaru!

Zniżki dla szkół!

Gwarantowany abonament

na laaata... (B 66-67).

[Farewell... no, welcome!

actors made up with lipstick of ash

predisposed

to act a real one-act play

entitled Ghetto is burning again!

It is a jewel of our repertoire!

Discounts for the schools!

Subscription guaranteed

for years...]

We will move back to a drama entitled Travel of my wife's parents to Treblink $\mathrm{a}^{15}$ published in 2003. Similarly to a majority of the writer's texts, it comprised touchy questions and provocative depictions. He festered. In this work, a lager experience originating partially from an autobiographical, partially a thematic version of himself, (one of drama characters is Marian Pankowski, "a former prisoner of German camps"), the writer considered - by power of his creative imagination - the Treblinka death camp. He also described a remembrance place left after this camp, perhaps processing the experience of a real journey ${ }^{16}$. Apart from motifs picked up in the work - a silent God and the indifference of Polish people and American Jews to Shoah ${ }^{17}$ - two questions especially catch the reader's attention:

${ }^{15}$ Idem, Podróż rodziców mej żony do Treblinki, "Dialog" 2003, issue 12. I locate quotations directly in the text, preceding number of the page with letter P.

${ }^{16}$ On autobiographism of this drama and its biographical layer, regarding the writer's wife see: O pamięci można nieskończenie. Rozmowa z Marianem Pankowskim, interviewed by D.J. Ćirlić, "Dialog" 2003, issue 12, p. 75.

${ }^{17}$ A teacher that guides a group of Jewish high school students through the memorial complex in Treblinka, a Jew himself, explains: "In those years... on this land... something hundred times worse than wolves bred... indifference! Poor and ignorant people were watching trains carrying Jews here... as if they were watching a rat catcher who using his squeaky flute takes from cities and towns... bearded, side curled rats... shunning holy water!" (P 67); "In those years on the free and rich land... egoism bred... It was more cruel than any wolf pack ... And it was easy for those rich and free ones to 'disbelieve'. [...] 'What - they were surprised - putting people into the 
the showing of the so-called Sonderkommando prisoners at work, busy removing traces of mass crime, a question of commemorating one of the biggest cemeteries in the world and the broader, institutionalizing of memory - deforming the truth.

Although the author of the drama consistently maintained the illusion, emphasizing a theatrical dimension of the space shown, a scene of taking out jewelry from gassed corpses in the gas chamber moves and shocks. Presentations of gas chambers in art aroused and still arouse controversy. Pankowski not only showed the place but also revealed a dehumanized attitude of the so-called Sonderkommando members to their brothers (so, putting it less pathetically, murdered people) in a drastic way, saturating the language with vulgarisms ("What the fuck did they eat yesterday?!" (P 72)) and telling jokes of a sexual nature. Here is a fragment of such a scene:

III (speaking with a strange voice) Hey men? I found at hers here a ring... the one with a gem!

I (laughing) Aaaaa... Engaged! A... a big stone!

II Maybe she got it from him... this one lying next to her... and yesterday he was swinging on her!

III Fuck it! She's a virgin...

I Whaaaat?

III Look! And?

III Oh yeaaaah! A virgin!

They rummage through intimacies of the poor wretches in silence (P 73).

It is hard not to pick up an issue of appropriateness regarding this fragment. The limits of decorum are movable on the axis of time, moreover they are different in the case of specific receivers. This knowledge I have regarding the topic of the functioning of "special working teams" allows me to see this scene as acceptable as far as it is moving us nearer, disregarding taboos, to the truth. A shocking dialogue in Pankowski's work is motivated because it presents "lagered" people (familiar with the specific camp morality). Perhaps my tolerance, although not devoid of hesitations, derives from the fact that I assume in agreement with an unwritten norm that someone who was there (in lager, friendly with death) is allowed to express more.

Let's move to the other question connected with Travel... For Pankowski, a husband of a Polish Jew, whose parents and younger brother died in the camp, Lager and Shoah connected with each other early, which is shown in the abovementioned poem entitled Auschwitz or this passage from a novel entitled The Pilgrims from Motherland (Patnicy z Macierzyzny): "I was tracking [a thick smoke

furnace? And after that only smoke and ash?! Where? Oh, there... in the end of the world where the Devil says 'good night!'. And they disbelieved" (ibidem). 
- A.M.], as it was climbing Auschwitz sky, up, where The Holy Spirit was hovering in a pink cloud of Jewish children"18. A lot of time had to pass (it is somewhat emblematic for the Polish culture, Polish historical memory) so that a writer clearly - in Travel... connected two Happenings creating a work of art belonging to both lager literature and the Holocaust literature (but leaning more to the latter). This is - I will add - a provocative and critical work of art. It is in the final scene of the drama, taking place on the site of a former death camp (and precisely located in time: 27 September 1977), that the writer ordered one of the visitors to ask a difficult question, reflecting long term politics of Poland, and more precisely that of the Polish People's Republic, regarding the memory of Shoah:

TOURIST 1 I am puzzled by the information here in this inscription... (he is pointing with his hand) It lacks one, the only one word... that would name the ethnic affiliation, and simultaneously religious one of thousands of victims...

A GUIDE (embarrassed) As a historian... I share your remark. (he sighs and smiles in fatherly way) Administration... always this administration... They didn't think that data should have been mentioned... so to say... encyclopedic... well... numbers, dates, transports... I assume that someone "at hand", a sentimental person was entrusted... someone sensitive to human suffering and simultaneously suffering of the community he belonged to... that's why "victims" are in plural here... that's why the “occupier's barbarity" (P 73) 19 .

Pankowski's drama and his other works recalled by me, among them these raising the lager topic, make us aware of one more important question. Namely that artistry, artificiality - in the case of the author of From Auschwitz to Belsen manifest themselves in the sphere of style through grotesque and disillusionment (this operation is exposed in dramas) - does not have to eclipse the seriousness of the drama. A declared abandoning of literacy by many authors, in war time and after the war, turned out to have been - it can be seen clearly from the present day point of view - a search for new, more accurate artistry ${ }^{20}$. These were mainly, although not all of them, those searchers of new forms, that created (with Borowski at the spearhead) works whose meaning exceeded, very important of course, the virtues of documentation ${ }^{21}$ - documentation in a broad sense: Lager and Shoah as

${ }^{18}$ M. Pankowski, Pątnicy z Macierzyzny, Oficyna Poetów i Malarzy, London 1985, p. 85.

${ }^{19}$ A similar, peculiar content was on the plate commemorating the death camp in Sobibór, "that omitted Jews among 250000 victim, even though it was a camp designed to annihilate them" (R. Traba, Symbole pamięci: II wojna światowa w świadomości zbiorowej Polaków. Szkic do tematu, in: idem, Kraina tysiaca granic. Szkice o historii i pamięci, Stowarzyszenie WK Borussia, Olsztyn 2003, p. 190).

${ }^{20}$ See J. Jedlicki, Dzieje doświadczone i dzieje zaświadczane, in: Dzieło literackie jako źródto historyczne, Z. Stefanowska, J. Sławiński (eds.), Czytelnik, Warsaw 1978, p. 351.

${ }^{21}$ See interview with M. Głowiński in: Zapisywanie zagłady. Z Michałem Głowińskim rozmawia Anka Grupińska, "Kontrapunkt" (added to "Tygodnik Powszechny") 2001, issue 1/2, p. 14. 
concrete and as social or cultural facts. This is what Jan Błoński mentioned (and what happened) in his perceptive essay entitled Extermination of literature and literature of extermination in 1965:

The one $[\ldots]$, who wants to reach the zero degree of literature, abandon everything what is hypocritically added form, the word, the one who wants to "give voice to events", risks that his voice will resound only as long as the direct memory of the events described is lasting ${ }^{22}$.

Leaving depositaries of memory, representatives of the generation remembering The Second World War and the Holocaust is one of the most important reasons for intensifying this formal search, the effect of which is that more and more works are regarded as bold, sometimes even inappropriate ${ }^{23}$. It can be said that Marian Pankowski, who passed away in 2011 - as one of the last ("saved people") - had the immunity to write such works. And he used it fully.

\section{Bibliography}

Błoński Jan, Zagłada literatury i literatura zagłady, "Współczesność" 1965, issue 18, pp. 1; 7.

Głowiński Michał, Zapisywanie zagłady. Z Michałem Głowińskim rozmawia Anka Grupińska, "Kontrapunkt" (added to "Tygodnik Powszechny") 2001, issue 1/2, pp. 4-15.

Jedlicki Jerzy, Dzieje doświadczone i dzieje zaświadczane, in: Dzieło literackie jako źródto historyczne, Zofia Stefanowska, Janusz Sławiński (eds.), Czytelnik, Warsaw 1978, pp. 344-371.

Krupiński Piotr, "Prawujac się z milczacym Bogiem". Mariana Pankowskiego rozrachunki auszwickie, in: Ślady obecności, Sławomir Buryła, Alina Molisak (eds.), Universitas, Cracow 2010, pp. 155-165.

Morawiec Arkadiusz, Lagerland, czyli o rzeczywistości w topos przemienionej, in: idem, Literatura w lagrze, lager $w$ literaturze. Fakt-temat-metafora, Wydawnictwo WSHE w Łodzi, Łódź 2009, pp. 293-311.

Morawiec Arkadiusz, Zmagania z tematem lagrowym w twórczości Mariana Pankowskiego, in: idem, Literatura $w$ lagrze, lager $w$ literaturze. Fakt-temat-metafora, Wydawnictwo WSHE w Łodzi, Łódź 2009, pp. 257-274.

O pamięci można nieskończenie. Rozmowa z Marianem Pankowskim, interviewed by D.J. Ćirlić, "Dialog" 2003, issue 12, pp. 75-77.

Pankowski Marian, Auschwitz. Fragment poematu, in: idem, Pieśni pompejańskie, R.-J. Stenuit, Bruxelles 1946.

22 J. Błoński, Zagłada literatury i literatura zagłady, "Współczesność" 1965, issue 18, p. 7.

${ }^{23}$ See A. Morawiec, Lagerland, czyli o rzeczywistości w topos przemienionej, in: idem, Literatura $w$ lagrze... Among the works published lately in Polish language that raise the topic of Shoah in a not fully appropriate (or at least regarded as controversial) manner we can mention: a volume by Piotr Macierzyński's poems Antologia wierszy ssmańskich (Cracow 2011), a novel by Igor Ostachowicz Noc żywych Żydów (Warsaw 2012) and a collection of Krystian Piwowarski's short stories Więcej gazu, Kameraden (Warsaw 2012). 
Pankowski Marian, Była Żydówka, nie ma Żydówki, Wydawnictwo Krytyki Politycznej, Warsaw 2008.

Pankowski Marian, Chrabąszcze (Widowisko narodowe choć wyssane z palca), in: Polski dramat emigracyjny 1939-1969. Antologia, Dobrochna Ratajczakowa (ed.), Lektor, Poznań 1993, pp. 858-892.

Pankowski Marian, Homer, in: idem, Sto mil przed brzegiem, PIW, Warsaw 1958.

Pankowski Marian, a letter to A. Morawiec from 25 September 2002 (in the possession of the addressee).

Pankowski Marian, Matuga idzie. Przygody, nakład własny autora, Bruxelles 1959.

Pankowski Marian, Pątnicy z Macierzyzny, Oficyna Poetów i Malarzy, London 1985.

Pankowski Marian, Podróż rodziców mej żony do Treblinki, "Dialog” 2003, issue 12, pp. 66-74.

Polak $w$ dwuznacznych sytuacjach. Z Marianem Pankowskim rozmawia Krystyna Ruta-Rutkowska, Instytut Badań Literackich PAN, Warsaw 2000.

Traba Robert, Symbole pamięci: II wojna światowa w świadomości zbiorowej Polaków. Szkic do tematu, in: idem: Kraina tysiaca granic. Szkice o historii i pamięci, Stowarzyszenie WK Borussia, Olsztyn 2003, pp. 179-198.

W literaturze jestem Żydem, [an interview with M. Pankowski] interviewed by K. Janowska, "Gazeta na Święta", added to "Gazeta Wyborcza" 2007, issue 300, pp. 20-21.

Arkadiusz Morawiec

\section{Shoah in Marian Pankowski's Literary Art}

\section{(Summary)}

The article centers on the theme of the Holocaust in the literary works of Marian Pankowski: its sources, relations with the concentration camp theme, particular works and their poetics, as well as the aesthetic, social and political problems related to the theme of the Holocaust.

Keywords: Polish literature, Marian Pankowski, Holocaust, Holocaust literature, concentration camp literature 